\title{
EUGLOSSINE BEES (HYMENOPTERA: APIDAE) OF BURITICUPU, AMAZONIA OF MARANHÃO, BRAZIL ${ }^{1}$
}

\author{
Francinaldo Soares SILVA², José Manuel Macário REBÊLO ${ }^{3}$
}

ABSTRACT - Male euglossine bees attracted to cineole, vanillin, methyl salicylate, eugenol and benzyl benzoate, were collected from October 1995 to September 1996, twice a month, between 06.00 and 12.00 hours, at the Companhia Vale do Rio Doce Forest Reserve, BuriticupuMA. It were sampled 1740 individuals, 37 species and 4 genera. Euglossa was the most abundant genus (23 species), followed by Eufriesea (8), Eulaema (4) and Exaerete (2). The most frequent species were Euglossa pleosticta (33\% of the collected individuals), Euglossa truncata (12,7\%), Euglossa avicula (6,3\%), Eufriesea superba (5,2\%), Euglossa fimbriata (4,8\%) Euglossa violaceifrons $(4,4 \%)$, Eulaema nigrita $(4,1 \%)$, Euglossa cordata $(4,0 \%)$, Eulaema meriana $(3,4 \%)$. Cineole attracted $66 \%$ of males and $70 \%$ of species, vanillin $(20 \% ; 59 \%)$, methyl salicylate $(7,4 \%$; $54 \%)$, eugenol $(5,6 \% ; 44 \%)$ and benzyl benzoate $(0,7 \% ; 10,8 \%)$. The highest abundance of individuals $(78,3 \%)$ and species (34) occurred in the rainy season (January-June). The species of the genus Eufriesea occurred only in this period. Regarding the hourly activity, the euglossine bees were more frequently found between 10.00 and 11.00 hours, accounting for $33,5 \%$ of the individuals and $86,4 \%$ of the species.

Key-words: bees, Euglossinae, Amazonia of Maranhão

\section{Abelhas Euglosssinae (Hymenoptera: Apidae) de Buriticupu, Amazônia maranhense, Br.azil}

RESUMO - Machos de Euglossinae atraidos por cineol, vanilina, salicilato de metila, benzoato de benzila e eugenol, foram coletados de outubro de 1995 à setembro de 1996, quinzenalmente, das 06:00 às 12:00 horas, na Reserva Florestal da Companhia Vale do Rio Doce (CVRD), em Buriticupu-MA. Foram coletadas um total de 1740 individuos pertencentes a 37 espécies de 4 gêneros, Euglossa foi o mais comum (23 espécies), seguido por Eufriesea (8), Eulaema (4) e Exaerete (2). As espécies mais freqüentes foram Euglossa pleosticta (33\% dos individuos coletados), Euglossa truncata (12,7\%), Euglossa avicula (6,3\%), Eufriesea superba $(5,2 \%)$, Euglossa fimbriata (4,8\%) Euglossa violaceifrons (4,4\%), Eulaema nigrita (4,1\%), Euglossa cordata $(4,0 \%)$, Eulaema meriana $(3,4 \%)$. Cineol atraiu $66 \%$ dos machos e $70 \%$ das espécies, vanilina $(20 \% ; 59 \%)$, salicilato de metila $(7,4 \% ; 54 \%)$, eugenol $(5,6 \% ; 44 \%)$ e benzoato de benzila $(0,7 \% ; 10,8 \%)$. A maior abundância de indivíduos $(78,3 \%)$ e espécies $(34)$ ocorreu na estação chuvosa (janeiro-junho). As espécies do gênero Eufriesea ocorreram somente neste periodo. $\mathrm{O}$ intervalo com maior atividade foi entre 10 e 11 horas (33,5\% dos individuos e $86,4 \%$ das espécies).

Palavras-chave: abelhas, Euglossinae, Amazônia maranhense

\section{INTRODUCTION}

Euglossine bees are known as "the orchid bees", due to the behavior of taking up aromatic substances mainly from the orchids (Dodson et al., 1969) probably as part of their mating procedure (Vogel, 1966; Williams \& Witthen, 1983 ).

Several compounds have already

1. Financial support: Companhia Vale do Rio Doce-CVRD and CNPq (Conselho Nacional de Desenvolvimento Científico e Tecnológico)

2. Biologist - Departmento de Biologia, Universidade Federal do Maranhão-Brazil

3. Entomologist - Departmento de Patologia, Universidade Federal do Maranhão - Praça Madre Deus, $n^{\circ} 02$ CEP 65.025-560 São Luis, Maranhão-Brazil 
been identified and isolated from the orchid fragrances (Dodson \& Hills, 1966; Hills et al., 1968, 1972; Dodson et al., 1969; Dodson, 1970; Williams \& Dodson, 1972) and some of these compounds have been utilized, as scent baits, in the faunistic inventories carried out in different areas of the neotropical region, such as Panamá (Ackerman, 1983, 1989; Roubik \& Ackerman, 1987; Zimmerman \& Madriñan, 1988), Costa Rica (Janzen et al., 1982), Peru (Pearson \& Dressler, 1985) including Brazil where our understanding about euglossine is based upon researches performed in Central Amazonia (Powell \& Powell, 1987; Becker et al., 1991; Morato et al., 1992; Oliveira \& Campos, 1995), Bahia (Raw, 1989), Paraiba, (Bezerra pers. inf.), Northern São Paulo (Rebêlo \& Garófalo, 1991, 1997) and Rio Grande do Sul (Wittman et al., 1988).

In Maranhão the standardized studies (including monographic works) have been initiated only within the last decade, providing a consistent information on the composition of euglossine species in the northern section of the state (Gonçalves et al., 1996; Rebêlo \& Cabral, 1997).

This study consists of a survey on euglossine bees fauna undertaken at the Companhia Vale do Rio Doce (CVRD) Forest Reserve in Buriticupu, Amazonia of Maranhão, in agreement with a series of researches planned to be done in the entire State of Maranhão. This work is focused on studying the species richness, seasonal variation and the association between the males and the collected fragrances.

\section{MATERIAL AND METHODS}

\section{Study site}

The municipality of Buriticupu is situated between $4^{\circ}-5^{\circ} \mathrm{LS}$ and $45^{\circ}$ $30^{\prime}-47^{\circ} \mathrm{LW}$, in the Amazonia of Maranhão. The mean altitude is $200 \mathrm{~m}$. The region is characterized by a transitional weather between the amazonian wet and the semi-arid northeastern climate, with a 6-month dry (July-December) and 6-month rainy season (JanuaryJune), with an annual mean precipitation of $1800 \mathrm{~mm}$ (DNPM, 1973).

The kind of soil in the surveyed area is the yellow latosoil, occurring in both Terciaries and Cretaceous plateaus. The texture varies according to topographic situation and original material. The old, acid, good-drained and permeable soils are composed of argilous, sandy or sandy-clay sediments (DNPM, 1973).

The original vegetation, which is constituted by Dense Perennial Stationary Forest, has been devastated by timber exploration and agricultural projects and, to date, is represented by fragments of forests on some plateaus (DNPM, 1973).

Pindare river is the main waterflow in the region belonging to Mearim basin. The river is about $468 \mathrm{~km}$ long. The margins, once covered by plants that lie along the river, has endured an intense deforesting process in the latest years, contributing to the elevation of evaporation index especially during the dry period (DNPM, 1973). 
The actual study area was the boundary of an uncovered section $(600 \mathrm{~m} 2)$ located at the CVRD Forest Reserve, approximately $45 \mathrm{~km}$ from Buriticupu, at MR-006 highway which links BR-222 to the "Arame" community. The reserve goes through 10,000 hectares of Amazonian Forest surrounded by deforested areas due to wood exploration and agricultural activities.

\section{Scent baits}

Cineole, methyl salicylate, vanillin, eugenol and benzyl benzoate were the scent baits used to attract male euglossine bees. Five pellets of cotton suspended by a string were hooked in the branches, about $1,50 \mathrm{~m}$ over the ground, and dampened with the respective compounds every hour. The scent baits were kept 6 meters distant from one another.

\section{Sample}

The inventory was undertaken from October 1995 to September 1996, twice a month, between 6.00 and 12.00 hours. The attracted males were captured using an entomological net, killed in a recipient containing ethyl acetate $\left(\mathrm{C}_{4} \mathrm{H}_{8} \mathrm{O}_{2}\right)$ and finally stored in plastic bags. All collected specimens were identified by the authors and is deposited in the entomological collection of the Department of Biology, Federal University of Maranhão, Bacanga Campus, São Luís, Maranhão, Brazil.

\section{RESULTS}

Numbers of species, individuals and attractivity to baits

Males of 37 species, belonging to four genera, were attracted to the scent baits (table 1). Euglossa was the most common genus represented by 23 species, followed by Eufriesea (8), Eulaema (4) and Exaerete (2).

Euglossa pleosticta (33\% of the individuals), Euglossa truncata $(12,7 \%)$, Euglossa avicula (6,3\%), Eufriesea superba (5,2\%), Euglossa fimbriata (4,8\%) Euglossa violaceifrons (4,4\%), Eulaema nigrita $(4,1 \%)$, Euglossa cordata $(4,0 \%)$, Eulaema meriana $(3,4 \%)$ were the most abundant species. The others males together represented $22,1 \%$ of the total sample. Euglossa sp.1, Euglossa sp.2, Euglossa sp.3, Euglossa sp.4 and Euglossa sp.5 have been studied and appear to be new species.

Cineole was the most visited scent bait, attracting $66 \%$ of the males and $70 \%$ of all the species sampled (Tab. 1). Euglossa pleosticta, Euglossa truncata, Euglossa fimbriata, Euglossa cordata, Euglossa violaceifrons and Eulaema nigrita, were the species which preferably visited this bait.

Vanillin attracted $20 \%$ of the males and $59 \%$ of the species. Among the species found at vanillin, Euglossa pleosticta was the most frequent, however, when taking all baits into account, it preferred cineole. On the other hand, Eufriesea superba, Euglossa avicula and Eulaema cingulata were more commonly found at vanillin than at the others. Euglossa piliventris and Eulaema mocsaryi 
Table 1. Frequency of male Euglossinae bees collected at cineole (CI), eugenol (EG), methyl salicylate (MS), vanillin (VN) and benzyl benzoate (BB), in Buriticupu-MA, from October 1995 to September 1996.

\begin{tabular}{|c|c|c|c|c|c|c|}
\hline EUGLOSSINAE & C I & E G & MS & $\checkmark N$ & B B & TOTAL \\
\hline Eufriesea aff. $m$ acroglossa & 01 & & 13 & 01 & & 15 \\
\hline Eufriesea eburneocincta & 01 & & 01 & 01 & & 03 \\
\hline Eufriesea elegans & & & & 02 & & 02 \\
\hline Eufriesea nigrescens & & 02 & & 07 & & 09 \\
\hline Eufriesea ornata & & 06 & & & 05 & 11 \\
\hline Eufriesea pulchra & & & 11 & 01 & 04 & 16 \\
\hline Eufriesea superba & 23 & 01 & 02 & 65 & & 91 \\
\hline Eufriesea surinamensis & & & 01 & 07 & & 08 \\
\hline Euglossa augaspis & 06 & 19 & 10 & 15 & & 50 \\
\hline Euglossa avicula & 23 & & 02 & 84 & & 109 \\
\hline Euglossabidentata & 01 & 01 & 01 & 01 & & 04 \\
\hline Euglossa chalybeata & 25 & 01 & 12 & & & 38 \\
\hline Euglossa cognata & & & 29 & & & 29 \\
\hline Euglossa cordata & 68 & 01 & & & 01 & 70 \\
\hline Euglossa fim briata & 83 & & & 01 & & 84 \\
\hline Euglossa gaianii & 03 & & 06 & & & 09 \\
\hline Euglossa imperialis & 37 & & 12 & 05 & & 54 \\
\hline Euglossa liopoda & 05 & 01 & & & & 06 \\
\hline Euglossa modestior & 08 & & 01 & & & 09 \\
\hline Eugloss a piliventris & & & & 10 & & 10 \\
\hline Euglossa pleosticta & 46.7 & 14 & 01 & 95 & & 577 \\
\hline Euglossa securigera & 06 & 03 & & & & 09 \\
\hline Euglossa sp.1 & 01 & & & & & 01 \\
\hline Euglossasp.2 & & & 01 & & & 01 \\
\hline Euglossa sp.3 & 01 & & & & & 01 \\
\hline Euglossasp. 4 & 01 & & & & & 01 \\
\hline Euglossa sp. 5 & 01 & & & & & 01 \\
\hline Euglossa townsendi & 05 & & & & & 05 \\
\hline Euglossa truncata & 185 & 28 & 01 & 07 & & 221 \\
\hline Euglossa violaceifrons & 75 & & & 01 & & 76 \\
\hline Euglossa viridis & & & 01 & & & 01 \\
\hline Eulaem a cingula $a$ & & 13 & 01 & 27 & & 41 \\
\hline Eulaem a meriana & 33 & 01 & 22 & 03 & & 59 \\
\hline Eulaem a mocsaryi & & & & 01 & & 01 \\
\hline E ulaem a nigrila & 68 & & & 04 & & 72 \\
\hline Exaerete frontalis & 08 & 04 & 01 & 01 & & 14 \\
\hline Exaerete sm aragdina & 14 & 03 & & 12 & 03 & 32 \\
\hline TOTAL & 1149 & 98 & 129 & 351 & 13 & 1740 \\
\hline
\end{tabular}


were attracted exclusively to vanillin. Methyl salicylate attracted 7,4\% of the males and $54 \%$ of the species. Although visiting others baits, the following species showed a given preference for Methyl salicylate: Eufriesea aff. macroglossa, Eufriesea pulchra, and Euglossa gaianii. The exclusivity was shown by Euglossa cognata, Euglossa viridis and Euglossa sp.2.

Eugenol attracted $5,6 \%$ of the males and $44 \%$ of the species. This odor was not specific to any of the species. Euglossa augaspis and Eufriesea ornata were the most regular species at this chemical bait.

Benzyl benzoate was the least attractive compound, where $0,7 \%$ of the males and $10,8 \%$ of the species visited this odor. The species which visited this bait with more frequency were Eufriesea ornata, Eufriesea pulchra, Exaerete smaragdina and Euglossa cordata. No euglossine males were attracted preferably to this bait.

Seasonal fluctuation and hourly activity

The highest abundance of male euglossine bees has been found between January and June, during the rainy season (Tab. 2; Fig. 1). April and June $(21,6 \%$ and $15 \%$, respectively) were the months which showed the highest peak of individuals. The greatest number of species was found in February $(72,9 \%)$, followed by March and June, both presenting $59,4 \%$ of the species sampled.

The males frequency at the baits was higher in the rainy season (Janu-
ary-June) than in the dry one (JulyDecember). Only Euglossa securigera, Eulaema nigrita and Eulaema cingulata showed to be more frequently found in the dry period. August $(0,9 \%)$ and September $(1,1 \%)$ were the less visited months throughout the year of study.

Eufriesea species occurred only in the rainy season (Tab. 2). Males of Eufriesea ornata visited the baits in May and June. Eufriesea nigrescens, Eufriesea pulchra, Eufriesea surinamensis, Eufriesea aff. macroglossa and Eufriesea elegans visited the scent baits early in the wet season. The high number of individuals collected in March is associated with Eufriesea superba which accounted for $29 \%$ of the specimens. This species appeared in the entire rainy season and peaked in March ( $72,5 \%$ of the individuals).

During the course of the study the following species were always present: Euglossa pleosticta, Euglossa truncata, Euglossa fimbriata, Euglossa violaceifrons, Euglossa augaspis and Eulaema nigrita. The others were abundantly found in the wet season. The highest abundance of Euglossa imperialis and Euglossa violaceifrons took place in February; Euglossa pleosticta, Euglossa avicula, Euglossa cognata and Euglossa gaianii, in April; Euglossa truncata was more frequent in May; Euglossa chalybeata and Euglossa piliventris in June; Euglossa fimbriata and Euglossa cordata had their abundance peak in July. Euglossa townsendi visited the scent baits late in the wet season.

With regard to the hourly activ- 
Table 2. Seasonal fluctuation of Euglossinae bees collected at scent baits in Buriticupu-MA from October 1995 to September 1996.

\begin{tabular}{|c|c|c|c|c|c|c|c|c|c|c|c|c|c|}
\hline EUGLOSSINAE & JAN & FEB & MAR & APR & MAY & JUN & JUL. & AUG & SEP & OCT & NOV & DEC & TOTAL \\
\hline Eufriesea aff. macroglossa & & 03 & 12 & & & & & & & & & & 15 \\
\hline Eufriesea eburneocincta & & 01 & & 01 & & & 01 & & & & & & 03 \\
\hline Eufriesea elegans & & 01 & 01 & & & & & & & & & & 02 \\
\hline Eufriesea nigrescens & & 05 & 02 & 02 & & & & & & & & & 09 \\
\hline Eufriesea omata & & & & & 01 & 01 & & & & & & & 02 \\
\hline Eufriesea pulchra & & 02 & 01 & 06 & 06 & & & & & 01 & & & 16 \\
\hline Eufriesea superba & 01 & 05 & 66 & 11 & & 06 & 01 & & & 01 & & & 91 \\
\hline Eufriesea surinamensis & & 07 & 01 & & & & & & & & & & 08 \\
\hline Eugiossa augaspis & 08 & 08 & 03 & 04 & 05 & 05 & 01 & & 02 & 02 & 05 & 06 & 50 \\
\hline Euglossa avicula & & 63 & 11 & 32 & 02 & 01 & & & & & & & 109 \\
\hline Euglossa bidentata & 01 & 02 & & 01 & & & & & & & & & 04 \\
\hline Euglossa chalybeata & 03 & 05 & 04 & 07 & 05 & 09 & & & 02 & 01 & 02 & & 38 \\
\hline Eugiossa cognata & & 07 & 01 & 09 & 07 & 04 & & & & & & 01 & 29 \\
\hline Euglossa cordata & & 02 & 01 & & & 05 & 22 & 03 & 02 & 15. & 17 & 03 & 70 \\
\hline Euglossa fimbriata & & 01 & & 02 & 01 & 09 & 31 & 03 & 02 & 12 & 19 & 04 & 84 \\
\hline Euglossa gaianii & & & & 03 & 01 & 01 & & & & 01 & & 02 & 09 \\
\hline Euglossa imperialis & & 15 & 06 & 03 & 08 & 08 & 06 & & & 06 & 02 & & 54 \\
\hline Euglossa liopoda & & 03 & 01 & & & 01 & 01 & & & & & & 06 \\
\hline Euglossa modestior & 01 & 01 & 01 & & 02 & 03 & & & & 01 & & & 09 \\
\hline Euglossa piliventris & & & & 04 & & 05 & & & & 01 & & & 10 \\
\hline Eugiossa pleosticta & 01 & 70 & 65 & 240 & 59 & 123 & 13 & & 01 & 01 & 04 & & 577 \\
\hline Euglossa securigera & & 01 & & & 01 & & & 01 & & 01 & 03 & 02 & 09 \\
\hline Euglossa sp.1 & & & & & & & & & & 01 & & & 01 \\
\hline Euglossa sp.2 & & 01 & & & & & & & & & & & 01 \\
\hline Euglossa sp. 3 & & & & & & 01 & & & & & & & 01 \\
\hline Euglossa sp. 4 & & & & & & & & & 01 & & & & 01 \\
\hline Euglossa sp. 5 & & & & & & & & & & 01 & & & 01 \\
\hline Euglossa tounsendi & & & & & & 02 & 02 & & & & 01 & & 05 \\
\hline Euglossa truncata & 03 & 18 & 29 & 27 & 80 & 38 & 11 & 01 & & 02 & 11 & 01 & 221 \\
\hline Euglossa violaceifrons & 01 & 14 & 07 & 04 & & 12 & 11 & 06 & 02 & 04 & 09 & 06 & 76 \\
\hline Euglossa viridis & & 01 & & & & & & & & & & & 01 \\
\hline Eulaema cingulata & 01 & 05 & 05 & 02 & 01 & 08 & & & 01 & 06 & 09 & 03 & 41 \\
\hline Eulaema meriana & & 07 & 06 & 16 & 10 & 05 & 04 & & & 02 & 05 & 04 & 59 \\
\hline Eulaema mocsaryi & & & 01 & & & & & & & & & & 01 \\
\hline Eulaema nigrita & 02 & & 01 & & 08 & 09 & 08 & 02 & 04 & 24 & 13 & 01 & 72 \\
\hline Exaerete trontalis & & 03 & & 02 & 06 & & & & & & 01 & 02 & 14 \\
\hline Exaerete smaragdina & 01 & 06 & 04 & & 03 & 05 & & & 02 & 02 & 05 & 04 & 32 \\
\hline TOTAL & 23 & 258 & 229 & 376 & 215 & 261 & 112 & 16 & 19 & 85 & 106 & 39 & 1740 \\
\hline
\end{tabular}




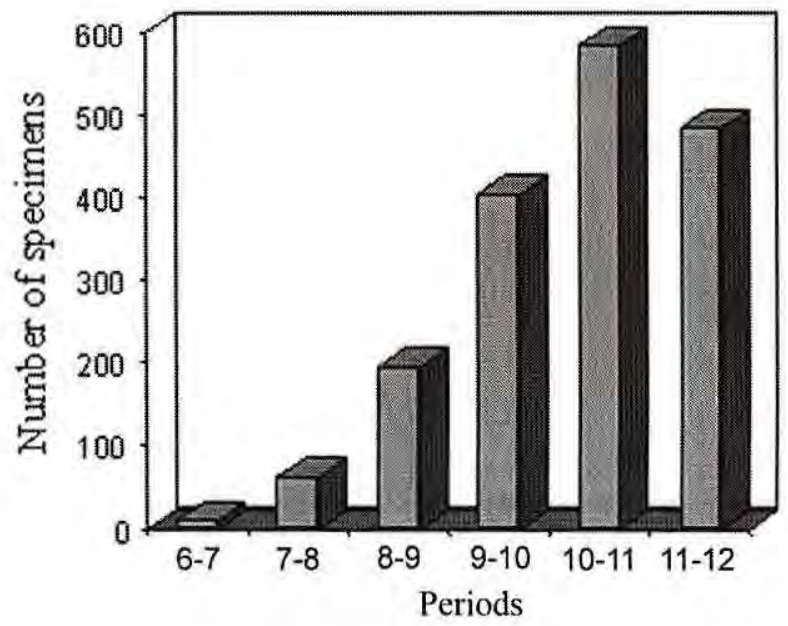

Figure 1. Seasonal fluctuation of euglossine bees collected at scent baits in Buriticupu-MA from October 1995 to September 1996.

ity, the euglossine bees showed increased active between 10.00 and 11.00 hours $(33,5 \%$ of the individuals and $86,4 \%$ of the species) followed by the period between 11.00 and 12.00 hours $(27,7 \%$ of the individuals and $78,3 \%$ of the species) (Tab. 3; Fig. 2). Eufriesea superba, Eulaema nigrita and Eulaema cingulata occurred in all intervals (from 06.00 to 12.00 hours). The abundance peak of Eufriesea superba was between 10.00 and 11.00 . Eulaema nigrita were more frequent between 09.00 and 10.00, Eulaema cingulata between 08.00 and 09.00 . Euglossa chalybeata and Eulaema cingulata between 08.00 and 09.00 and Eufriesea surinamensis, Eufriesea aff. macroglossa, Euglossa truncata and Eulaema nigrita between 09.00 and 10.00 (Tab. 3).

\section{DISCUSSION}

The fauna of euglossine bees found in the RDCV Forest Reserve was more abundant and diversified than that encountered in others surveyed areas in the State of Maranhão. This finding agrees with the stated point that the wet tropical forests indeed hold the areas in which bees reach increased richness (Ducke, 1902; Dressler, 1982). The high number of species sampled in the present work set Buriticupu as one of the wealthiest region in Brazil, in euglossine bees attracted to scent baits, only comparable to the central Amazonian region (Oliveira \& Campos, 1995). These authors have found 32 and 36 species at two distinct areas in this region, respectively, using eight kinds of scent compounds. The 


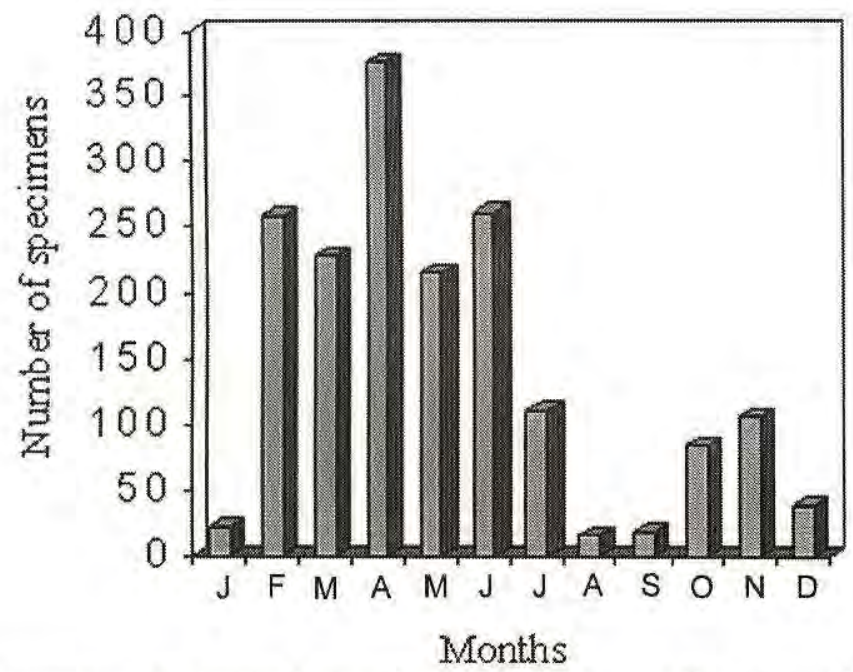

Figure 2. Frequency of euglossine bees collected at scent baits in Buriticupu-MA, in relation to daily activity (from 06.00 A.M. to 12.00 A.M.), from October 1995 to September 1996.

current study although utilizing only 5 scent baits and carried out at the boundaries of an open area in the forest environment, sampled 37 species, of which 15 were not found in the Central Amazonia. These differences may be due to the transitional position occupied by Maranhão among the macro-regions (Amazonian Forest, Cerrado and Caatinga) which characterize Brazil, since the fauna encountered in Buriticupu, although dominant by Amazonian species, also possesses common elements from the northeast and central-south Brazil fauna, as already observed by Rebêlo \& Cabral (1997).

Among bees, Euglossa is the most diversified genus holding a large variety of species spread all over the Neotropics. This variety was present in Buriticupu where Euglossa was represented by several species occurring all year round. Euglossa pleosticta was the most abundant species and has previously been found only in southsoutheast Brazil (south Bahia down to northeast São Paulo, Rio de Janeiro, Espírito Santo, Minas Gerais). Therefore, this work presents the first data of this species in the north Brazil. Euglossa violaceifrons and Euglossa truncata also follows this distribution pattern, since they have been described from the semidecidual forest of northeast São Paulo State (Rebêlo $\&$ Moure, 1995) with no records, thus far, on these euglossine bees has been found rather than south Brazil. Together with the two latter species is Euglossa avicula which former reports comes from north (Oliveira \& Campos, 1995) and south Brazil (Dressler, 1982). On this basis, these species show a discontinuous distribution pattern since they have not been encountered in the areas situated in northeastern areas of Brazil such as Bahia and Paraiba, where inventories have al- 
Table 3. Frequency of Euglossinae males collected at scent baits in Buriticupu-MA, in relation to daily actvity (from 06.00 A.M. to 12.00 A.M.), from October 1995 to September 1996.

\begin{tabular}{|c|c|c|c|c|c|c|c|}
\hline EUGLOSSINAE & 06.07 & 07.08 & 08.09 & 09.10 & $10-11$ & $11-12$ & TOTAL \\
\hline Eutriesea aft. $m$ acroglossa & & 01 & 02 & 07 & 04 & 01 & 15 \\
\hline Eufriesea eburneocincta & & & & & 01 & 02 & 03 \\
\hline Eufriesea elegans & & & & & 02 & & 02 \\
\hline Eufriesea nigrescens & & 01 & 01. & 04 & 03 & & 09 \\
\hline Eufriesea ornata & & & 02 & 03 & 04 & 02 & 11 \\
\hline Eufriesea pulchra & & & 01 & 02 & 07 & 06 & 16 \\
\hline Eufriesea superba & 01 & 02 & 05 & 22 & 33 & 28 & 91 \\
\hline Eufriesea surinamensis & & & 03 & 04 & 01 & & 08 \\
\hline Euglossa augaspis & & 03 & 05 & 06 & 16 & 20 & 50 \\
\hline Euglossa avicula & & 02 & 07 & 11 & 46 & 43 & 109 \\
\hline Euglossa bidentata & & & & & & 04 & 04 \\
\hline Euglossa chalybeata & & 11 & 13 & 05 & 05 & 04 & 38 \\
\hline Euglossa cognata & & 01 & 01 & 02 & 16 & 09 & 29 \\
\hline Euglossa cordata & & & 04 & 14 & 29 & 23 & 70 \\
\hline Euglossa tim briata & & & 04 & 27 & 29 & 24 & 84 \\
\hline Euglossa gaianii & & & 01 & & 04 & 04 & 09 \\
\hline Euglossa imperialis & & 01 & 04 & 09 & 14 & 26 & 54 \\
\hline Euglossa liopoda & & & & & 05 & 01 & 06 \\
\hline Euglossa modestior & & & & 04 & 04 & 01 & 09 \\
\hline Euglossa pliventris & & 01 & & & 02 & 07 & 10 \\
\hline Euglossa pleosticla & & 27 & 71 & 146 & 213 & 140 & 577 \\
\hline Euglossa securigera & & & 03 & & 04 & 02 & 09 \\
\hline Euglossa sp.1 & & & & & 01 & & 01 \\
\hline Euglossa sp.2 & & 01 & & & & & 01 \\
\hline Euglossasp.3 & & & & & 01 & & 01 \\
\hline Euglossa sp.4 & & & & & & 01 & 01 \\
\hline Euglossa sp. 5 & & & & & 01 & & 01 \\
\hline Euglossa townsondi & & & & & 03 & 02 & 05 \\
\hline Euglossa truncata & & 01 & 25 & 73 & 65 & 57 & 221 \\
\hline Euglossa violaceifrons & & 01 & 05 & 12 & 27 & 31 & 76 \\
\hline Euglossa viridis & & & & & & 01 & 01 \\
\hline Eulaem a cingulata & 01 & 06 & 13 & 11 & 06 & 04 & 41 \\
\hline Eulaema meriana & 04 & 09 & 08 & 07 & 15 & 16 & 59 \\
\hline Eulaem a mocsaryi & & & 01 & & & & 01 \\
\hline Eulaema nigrita & 03 & 16 & 11 & 21 & 10 & 11 & 72 \\
\hline Exaerete frontalis & & & & 02 & 08 & 04 & 14 \\
\hline Exaerete sm aragdina & & & 07 & 10 & 06 & 09 & 32 \\
\hline TOTAL & 10 & 63 & 194 & 404 & 583 & 483 & 1740 \\
\hline
\end{tabular}


ready performed, thus restraining their occurrence to south and north Brazil (Buriticupu region in the case of Euglossa pleosticta and Euglossa truncata). As the four above-mentioned species, Euglossa augaspis, Euglossa bidentata, and Euglossa viridis are found for the first time in Maranhão State. The three latter bess are Amazonian species without records to sub-amazonian areas in Brazil, which a drier weather is characteristically found, forcing them to have a limited occurrence in the amazon basin. The others species have a large distribution in Brazil.

Attention is given to the occurrence in Buriticupu of Euglossa sp. 1, Euglossa sp.2, Euglossa sp.3, Euglossa sp.4 and Euglossa sp.5, which apparently represent undescribed species. Interestingly, as the field works are intensified new species and a increasing distribution of the known species may be found. Therefore, a frequent and extensive census work should be done so that the richness and distribution of male euglossine bees can be accurately predicted.

Several Eufriesea species have already been found in Maranhão, such as E. surinamensis, E. pulchra and $E$. ornata. The former is a panneotropical, occurring in Alcântara, setentrional zone of Maranhão State (Gonçalves et al., 1996). The second occurs in Panama (Ackerman, 1983; Roubik \& Ackerman, 1987) and Amazonia (Braga, 1976; Oliveira \& Campos, 1995). The latter species has been recorded only in the Amazon Basin (Braga, 1976; Oliveira \& Cam- pos, 1995), Atlantic Forest in south Brazil (Kimsey, 1982) and in Barreirinhas, coastal zone of Maranhão State (Rebêlo \& Cabral, 1997). The following amazonian species have been recorded for the first time in Maranhão: $E$. aff. macroglossa, E. eburneocincta, E. elegans, E. nigrescens. Only Eufriesea nigrescens ranges beyond the amazonian domain, going as far as Paraguay.

The others species studied in this paper (Tab. 1) were found in different ecosystems in Maranhão State (see Rebêlo \& Cabral, 1997). Curiously, Eulaema nigrita was one of the most frequent species sampled in CVRD Forest Reserve, the entrance area to the Amazonian Forest. Thus far, no record regarding this species was registered for this kind of environment, since Eulaema nigrita has been characterized as a typical species of open and relatively dry areas (Ducke, 1902; Zucchi et al., 1969), that is why it is not recorded in the census works performed in the central Amazonia using scent baits (Braga, 1976; Powell \& Powell, 1987; Becker et al., 1991; Morato et al., 1992; Oliveira \& Campos, 1995). However, in the sub-amazonian areas E. nigrita is frequently found associated with northeastern dry areas, as well as in the wet forests of São Luís (Gomes, pers. inf.), Bahia (Raw, 1989) and semidecidual forests of São Paulo State (Rebêlo \& Garófalo, 1991). The occurrence of Eulaema nigrita in the CVRD Forest Reserve is related likely to the fact that Buriticupu stays in a transitional zone 
placed between the Cerrado areas and the Amazonian Forest. The remaining species of the genus Eulaema sampled in this survey, such as E. meriana, E. mocsaryi and E. cingulata, are common in south America. Eulaema meriana belongs to a mimetic complex encountered in the Amazon basin, in such a group are included E. bombiformis and E. seabrai, not studied in this paper. Eulaema meriana occurs in the Amazonian region and in the coastal forests from Pernambuco down to Paraná, Brazil, but completely absent in the northeastern drought area named "sertão nordestino".

Regarding the Exaerete species, $E$. smaragdina and females of $E$. dentata have been found in Barreirinhas-MA (Rebêlo \& Cabral, 1997). The former are common in the north State. E. frontalis, as well as the others Exaerete are pan-neotropical species.

Cineole was the most visited scent bait at the CVRD Forest Reserve, corroborating the numerous works carried out with this chemical compound in Maranhão State and in several regions of Brazil (Raw, 1989; Rebêlo \& Garófalo, 1991; Morato et al., 1992). Vanillin also attracted a large number of individuals being the second most visited bait by euglossine species. The others utilized compounds were less attractive.

The highest abundance of euglossine bees was detected during the rainy season. The occurrence of bees in a given season is influenced by either nesting and emerging periods which in turn are influenced by tem- perature and moisture (Ackerman, 1983; 1989).

The species of Eufriesea exhibited a rigorous seasonal distribution appearing either in the wet season or in the dry season, depending on the involved species, according to the observations of others researchers in distinct areas of the Neotropics (Pearson \& Dressler, 1985; Roubik \& Ackerman, 1987; Wittman et al., 1988; Rebêlo \& Garófalo, 1991, 1997). Eufriesea pulchra was more frequent in the wet season with a sole individual in the dry period. Ackerman (1983) also verified the presence of this species in similar seasonal periods.

In August, the driest month of the study year, a low humidity, high temperature weather was detected and a low number of individuals and species visited the scent baits within this month. The captured species in this period were as follow: Euglossa cordata, Euglossa fimbriata, Euglossa securigera, Euglossa truncata, Euglossa violaceifrons and Eulaema nigrita. Such species visited the baits during all the year exhibiting a fluctuation only in the abundance of individuals.

In conclusion, the Buriticupu region is represented by a diversified and overlaid euglossine bees fauna which is formed by species commonly found either in the Amazonian basin and in distinct ecological Brazilian areas.

\section{AKNOWLEDGEMENTS}

We acknowledge the Conselho Nacional de Desenvolvimento Científico e Tecnológico (CNPq) and the Companhia Vale do Rio Doce- 
CVRD for supporting this research.

\section{Literature cited}

Ackerman, J. .D. 1983. Diversity and seasonally of male Euglossinae bees ( $\mathrm{Hy}$ menoptera: Apidae) in Central Panama. Ecology, 64: 274-283.

Ackerman, J. .D. 1989. Geographic and seasonal variation in fragrance choices and preferences of male Euglossinae bees. Biotropica, 21: 340-347.

Becker, P; Moure, J.S.; Peralta, F. J. A. 1991. More about euglossine bees in Amazonian Forest Fragments. Biotropica, 23: 586-591.

Braga, P.I.S. 1976. Atração de machos de abelhas polinizadoras de Orchidaceae com auxilio de iscas-odores na campina, campinarama e floresta tropical ümida da região de Manaus. Ciências $e$ Cultura, 28: 767-773.

DNPM - Projeto RADAM. 1973. Mapas de geologia e geomorfologia. Vol, 3: Folha SB-23 - Teresina e parte da Folha SB24 - Jaguaribe. Vol. 3: Folha SA - 23 São Luis e parte da Folha SA - 24 Fortaleza, Rio de Janeiro.

Dodson, C. H. 1970. The role of chemical attractants in orchid pollination. In: Chambers, K.L. (ed.). Biochemical Coevolution. Corvallis, OR: Oregon State Univ., p. 83-1077.

Dodson,C.H.; Hills, H.G. 1966. Gas chromatography of orchid fragrances. Amer: Orchid Soc Bull., 35: 720-725.

Dodson, C.H.; Dressler, R.L.; Hills, H.G.; Adams, R.M.; Williams, N.H. 1969 , Biologically active compounds in orchid fragrances. Science, 164: 1243-49.

Ducke, A. 1902. As espécies paraenses do gênero Euglossa Latr. Bio. Mus. Goeldi, 3: 561-575.

Dressler, R. L. 1982. Biology of orchid bees (Euglossini). Ann Rev. Ecol. Syst., 13: 373-94.

Gonçalves, S.deJ.M.; Rêgo, M.; Araújo, A. 1996. Abelhas sociais (Hymenoptera;
Apidae) e seus recursos florais em uma região de mata secundária, Alcântara, MA, Brasil. Acta Amazonica, 26: 55-68.

Hills, H.G.; Williams N.M.; Dodson, C.H. 1968. Identification of some orchid fragrances components. Amer: Orchid Soc. Bull., 37: 967-971.

Hills, H.G., Williams, N.H.; Dodson, C.H. 1972. Floral fragrances and isolating mechanisms in the genus Catasetum (Orchidaceae). Biotropica, 4: 61-76.

Janzen, D.H., De Vries, P.G., Higgins, M.L.; Kimsey, L.S. 1982. Seasonal and site variation in Costa Rican Euglossine bees at chemical baits in lowland deciduous and evergreen forests. Ecology, 63: 66-74.

Morato, E.F; Campos, L.A.; Moure, J. S. 1992. Abelhas Euglossini (Hymenoptera, Apidae) coletadas na Amazônia Central. Rev. Bras. Ent., 36: 767-771.

Oliveira, M.L.; Campos, L.A. O. 1995. Abundância, riqueza e diversidade de abelhas Euglossinae (Hymenoptera, Apidae) em florestas continuas de terra firme na Amazônia Central, Brasil. Revta Bras. Zool., 12: 547-556.

Pearson, D.L.; Dressler, R.L. 1985. Two-year study of male orchid bee (Hymenoptera: Apidae: Euglossini) attraction to chemical baits in lowland south-eastern Peru. J. Tropical Ecol., 1: 37-54.

Pereira-Martins, S.R.; Kerr, W.E. 1991. Biologia de Eulaema nigrita. 3. Inferências evolutivas. Papeis Avulsos Zool., 37: 245-250.

Powell, A.H.; Powell, G.V.N. 1987. Population dynamics of male Euglossine bees in Amazonian Forest fragments. Biotropica, 19: 176-179.

Raw, A. 1989. The dispersal of euglossine bees between isolated patches of eastern Brazilian wet forest (Hymenoptera, Apidae, Euglossini). Rev. Bras. Ent., 33: $103-$ 107.

Rebêlo, J.M.R.; Cabral, A.J. 1997. Abelhas Euglossinae de Barreirinhas, Zona do litoral da Baixada Oriental Maranhense. Acta Amazonica, 27: 145-152. 
Rebêlo, J.M.M.; Garófalo, C.A. 1991. Diversidade e sazonalidade de machos de Euglossini (Hymenoptera: Apidae) e preferências por iscas-odores em um fragmento de floresta no sudeste do Brasil._Rev. Brasil. Biol., 51: 787-799.

Rebêlo, J.M.M.; Garófalo, C.A. 1997. Comunidades de machos de Euglossini (Hymenoptera: Apidae) em matas semideciduas do nordeste do Estado de São Paulo. An. Soc. Entomol. Brasil, 26: 243-255.

Rebêlo, J.M.M.; MOURE, J.S. 1995. As espécies de Euglossa Latreille do Nordeste de São Paulo (Apidae, Euglossinae). Revta. Bras. Zool., 12: 445-466.

Roubik, D.W.; Ackerman, J.D. 1987. Longterm ecology of euglossine orchid-bees (Apidae: Euglossini) in Panama. Oecologia, 73: 321-333.

Vogel, S. 1966. Parfümsammelnde Bienen als bestaúber von Orchidaceen und Gloxinia._Oesterr, Bot. Zs., 113: 302-361.

Williams, N.H.; Dodson, C.H. 1972. Selective attraction of male euglossine bees to orchid floral fragrance and its importance in long distance pollen flow. Evolution, 26: 84-95.

Williams, N.H.; Witthen, W.M. 1983. Orchid floral fragrances and male euglossine bees. Methods and advances in the last sesquidecade. Biol. Bull., 164: 355-395.
Wittman, N,D; Hoffmann, M.; Scholz, E. 1988. Southern distributional limits of euglossine bees in Brazil linked to habitats of the Atlantic and Subtropical rain forest (Hymenoptera: Apidae: Euglossini). Entomol. Gener, 14: 53-60.

Zimmerman, J.K.; Madriñan, S.R 1988. Age structure of male Euglossa imperialis (Hymenoptera: Apidae: Euglossini) at nectar and chemical sources in Panama. Tropical Ecology, 4: 303-306.

Zucchi, R.; Sakagami, Sh.F.; Camargo, J.M.F. 1969. Biological observations on a notropical parasocial bee, Eulaema nigrita, with a review on the biology of Euglossinae (Hymenoptera, Apidae). A comparative study, J.Fac.Sci. Hokkaido Univ. Serv. VI, Zool., 17: 271-382. 